\section{Journal of Anatolian Environmental and Animal Sciences (Anadolu Çevre ve Hayvancılık Bilimleri Dergisi) \\ Doi: https://doi.org/10.35229/jaes.573842}

\section{JAES}

Year: 4, No: 2, $2019(243-250)$

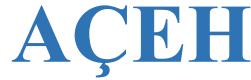

Yıl: 4, Sayı:2, $2019(243-250)$

\title{
A Case Study of Rural Area Hail Storm in Yomra, Trabzon, on August 31, $2017^{* * 1}$
}

\author{
Emrah Tuncay ÖZDEMIRR ${ }^{1,2^{*}}$ Oğuzhan KOLAY ${ }^{3}$ Omer YETEMEN ${ }^{2}$ \\ ${ }^{1}$ Turkish State Meteorological Service, Atatürk Airport Meteorology Office, Yesilkoy, Istanbul, Turkey. \\ (D): https://orcid.org/0000-0003-4764-1625 \\ ${ }^{2}$ Civil, Surveying and Environmental Engineering, The University of Newcastle, Callaghan, Australia. \\ (D): https://orcid.org/0000-0002-2335-2450 \\ ${ }^{3}$ Turkish State Meteorological Service, Milas-Bodrum International Airport Meteorology Office, Mugla, Turkey \\ (C): https://orcid.org/0000-0003-1593-3519
}

Received date: 06.06 .2018

Accepted date: 05.08.2019

How to cite: Özdemir, E.T., Kolay, O. \& Yetemen, O. (2019). A Case Study of Rural Area Hail Storm in Yomra, Trabzon, on August $31,2017$. Anatolian Env. and Anim. Sciences, 4(2), 243-250.

Atıf yapmak için: Özdemir, E.T., Kolay, O. \& Yetemen, O. (2019). Yomra (Trabzon) Kırsalında 31 Ağustos 2017’de Meydana Gelen Dolu Yağışının İncelenmesi. Anadolu Çev. ve Hay. Dergisi, 4(2), 243-250.

Abstract: On August 31, 2017, a hail storm occurred in a rural area in Yomra District of Trabzon Province. The hail storm occurred during the harvest season, and it did not cause significant losses on hazelnut production because hazelnuts had been fully grown. The hail storm was recorded, and some of the hail accumulations had been photographed by a mobile phone. Diameters of hail were approximately $1.5 \mathrm{~cm}$. In this study, the hail storm event is analysed by satellite and weather radar products obtained from Turkish State Meteorological Service. Also, the radar data analysed by Thunderstorm Identification, Tracking, Analysis and Nowcasting (TITAN) software, which is used for the first time in the analysis of meteorological events in Turkey. Here, it was discussed that the storm cell with $62.5 \mathrm{dBZ}$ reflectivity value is whether a "supercell" or not. Based on the TITAN analysis, the symptoms including the existence of weak echo region and bounded weak echo region, the observation of the V notch, relatively high precipitation flux (pflux) values, and the areal coverage, strengthen the likelihood of the thunderstorm cell to be a "supercell".

Keywords: Hail storm, satellite products, supercell, TITAN, Trabzon, weather radar.

\section{Yomra (Trabzon) Kırsalında 31 Ağustos 2017'de Meydana Gelen Dolu Yağıșının İncelenmesi}

Öz: 31 Ağustos 2017 tarihinde Trabzon Şehrinin Yomra ilçesinde dolu yağışı meydana gelmiştir. Fındık toplama zamanında meydana gelen dolu yağışı findıkların olgunlaşmış olması nedeniyle findıklara çok büyük zarar vermemiştir. Yomra'da meydana gelen dolu yağışı videoya kaydedilmiş ve yağıştan sonra da yerde biriken dolular yer yer fotoğraflanmıştır. Meydana gelen dolunun çapı yaklaşık $1.5 \mathrm{~cm}$ 'dir. Dolu yağışı Meteoroloji Genel Müdürlüğü'den elde edilen uydu görüntüleri ve radar görüntüleri kullanılarak analiz edilmiştir. Ayrıca sayısal analiz için Türkiye'de ilk defa kullanılan Thunderstorm Identification Tracking Analysis and Nowcasting (TITAN) yazılım programı kullanılmıştır. Bu çalışmada, 62,5 dBZ reflektivite değerine ulaşan oraj hücresinin "supercell” olup olmadığı tartışılmıştır. TITAN analizi sonucunda, eko bölgelerinin gözlenmesi, V çentigi, göreceli olarak yüksek yağiş akış değerleri ve alansal büyüklüğü gibi belirtiler bu dolu hadisesine neden olan oraj hücresinin supercell olması olasılı̆̆ını artırmaktadır. 


\section{INTRODUCTION}

A thunderstorm is defined as a weather phenomenon, which has showers with lightning and thunder. This severe weather phenomenon is generated by single or combined one or more cumulonimbus $(\mathrm{Cb})$ clouds and can cause rain, snowstorm, and hailstorm (Türkeş, 2010; Ackerman \& Knox, 2015). There are three types of thunderstorms: single-cell thunderstorms, multi-cell thunderstorms, and supercell thunderstorms (Türkeş, 2010; Ackerman and Knox, 2015). Single-cell storms are a few kilometres wide, while supercell storms are much broader. A lifetime of a single-cell storm is less than an hour, and supercell is about several hours. Multi-cell storms are composed of lines or batches of single-cell, supercell, or both of these types of storms (Ackerman \& Knox, 2015).

Supercell thunderstorms are the most infrequent but also the most damaging type among those three. A great number of the supercell thunderstorms produce large hail and tornado. They can rotate and tilt the upper movement (mesocyclone). Supercell thunderstorms generally have lifetimes from one up to four hours and even more in some cases. They are well-organized structures with strong environmental wind shear and internal dynamic processes. Supercells are likely to produce hook echo, weak echo region (WER), bounded, weak echo region (BWER) (Figure 1a) and $\mathrm{V}$ notch (Figure 1b) which can be detected by radar scans. They have front flank downdraft (FFD) and rear flank downdraft (RFD), and sometimes they cause to form wall cloud, tail cloud, and mammatus (Cotton \& Anthes, 1989; NWS, 2018).

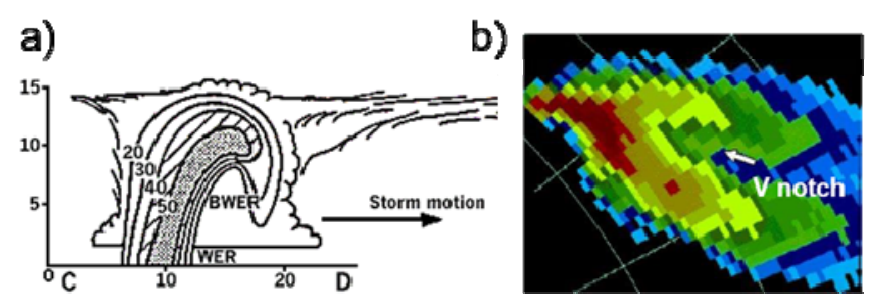

Figure 1. a) Weak echo region (WER) and bounded weak echo region (BWER) (Cotton \& Anthes, 1989; Chisholm \& Renick, 1972), b) V notch (Wikipedia 2018; NWS, 2018).

Nowadays, there are a lot of nowcasting and reanalysing systems in meteorology. Some of these systems are; Thunderstorm Identification Tracking Analysis and Nowcasting (TITAN) (Dixon \& Wiener, 1993), McGill Algorithm for Precipitation Nowcasting by Lagrangian Extrapolation (MAPLE) (Germann \& Zawadzki, 2002), Short-Term Ensemble Prediction System (STEPS) (Bowler et al., 2006) and the Short-range Warnings of Intense Rainstorms in Localized Systems (SWIRLS) (Li \& Lai, 2004). These reanalysis systems rely on measurements done by digital weather radar. In Turkey, there are 18 weather radars which are operated under the authority of Turkish State Meteorological Service (TSMS). Seventeen of them are
C-Band, and only one of them is X-band. The C-band radars are mostly located in mountainous regions. Nowcasting, weather forecast from current up to a six-hour period, is still operating human-based in Turkey, and the nowcasting systems are not conventional currently. Hence, there is a need to make these systems more widespread in Turkey. Here, a hail storm in Yomra is investigated as a case study by using one of these systems.

There are a lot of national and international studies about thunderstorms and supercells (Annanurov et al., 2014; Özdemir \& Deniz, 2014; Yazmuhammedov et al., 2014; Özdemir et al, 2015; Yavuz et al., 2015; Özdemir and Deniz 2016; Ozdemir et al., 2017; Özdemir et al., 2017; Markowski et al., 2018; Bunkers, 2018; King and Kennedy, 2019; Özdemir et al., 2019; Putnam, 2019). Recently, Kahraman et al. (2016) studied comprehensively the severe hail (diameter is equal to or greater than $1.5 \mathrm{~cm}$ ) climatology in Turkey. They compiled the severe hail events from meteorological observation, newspapers, and internet sources for the period 1925-2014. They found 1489 reported severe hail cases. Almost entire Turkey is prone to severe hailstorms, and these events most frequently occur in spring and summer. Most of the hailstorms are observed in the afternoon and evening, 1200 UTC and 1459 UTC. Geographical distribution of hailstorms in Turkey is almost uniform. The time series of occurrence frequency show that they are peaked at the 1960s and a declining period until 2000 and followed by an increase towards 2014. Besides the meteorological factors, the increase in frequency during the recent decade can be attributed to the widespread usage of recording devices and broadcasting on the Internet (Kahraman et al., 2016).

Hail storm events draw attention in the public when they hit the metropolitan areas and cause economic losses. On July $27^{\text {th }}, 2017$, a severe hailstorm occurred in the city centre of Istanbul, which causes significant damages to vehicles and residences. This event draws attention as a case study. Most recently, Baltac1 et al. (2018) studied this extreme hailstorm observed between 1300 UTC and 1700 UTC in Istanbul on $27^{\text {th }}$ July 2017 . Hailstone diameters were about 3-6 cm. Excessive heating of sea surface temperature (SST) released a significant amount of moisture into the lowlevels of the atmosphere, which enhanced moisture convergence at these levels. The dramatic temperature difference between land and the 500-hPa level and strong wind shear increased thermal instability, which caused this phenomenon in Istanbul (Baltaci et al., 2018). Furthermore, we may face more frequently this event due to an increase in SST induced by global warming.

Aim of the study is to analyse the meteorological conditions which are related to the hailstorm that observed in Yomra district on $31^{\text {st }}$ August 2017. Thunderstorm Identification Tracking Analysis and Nowcasting (TITAN) is 
used for the first time in Turkey to analyse the radar data. Also, it is discussed that the convective cell that caused to hailstorm is a "supercell" or not.

\section{MATERIAL and METHOD}

Event Description: On August 31 ${ }^{\text {st }}$, 2017, the hailstorm started at 1317 UTC (1817 local time) and lasted about 5-6 minutes in Tahir Çalık's hazelnut farmland which is in Yomra District, Trabzon Province (Figure 2). Coordinates of the farmland are $40^{\circ} 55^{\prime} 03.6 " \mathrm{~N}$ $39^{\circ} 53^{\prime} 29.5^{\prime \prime E}$. Elevation of the farmland is $422 \mathrm{~m}$ above sea level, and the distance between the farmland and the Black Sea is nearly $4.1 \mathrm{~km}$. The hailstorm event was recorded and photographed by a smartphone camera (Figure 3a). The captured video of the event can be found on the Internet (https://www.youtube.com/watch?v=9IyFMXfAX1c). The hail size measured after the hailstorm event was $1.5 \mathrm{~cm}$. It should be considered that hailstone melts while picking up and measuring (Figure $3 b$ ).

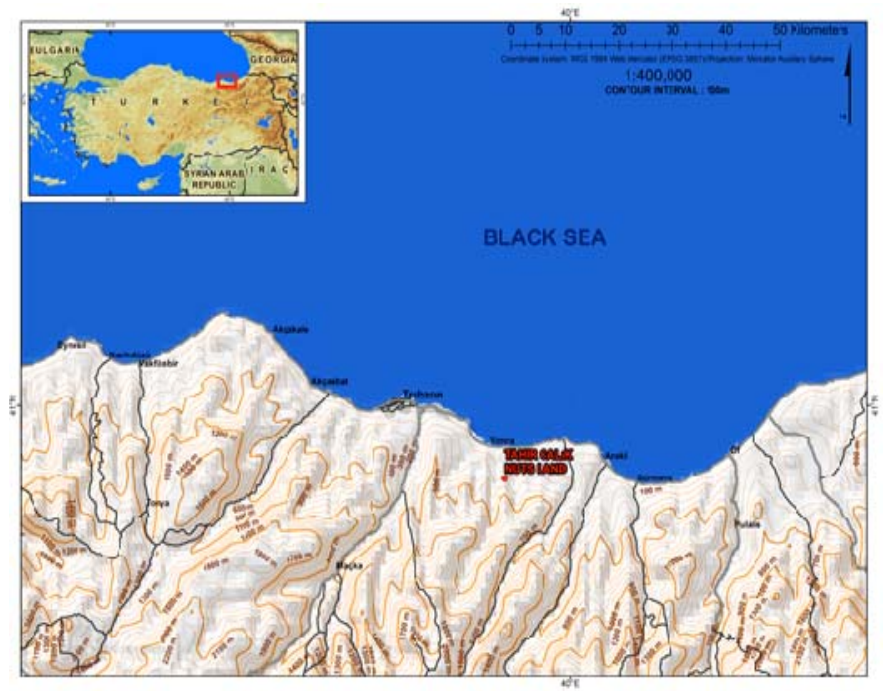

Figure 2. The location map of the farmland.

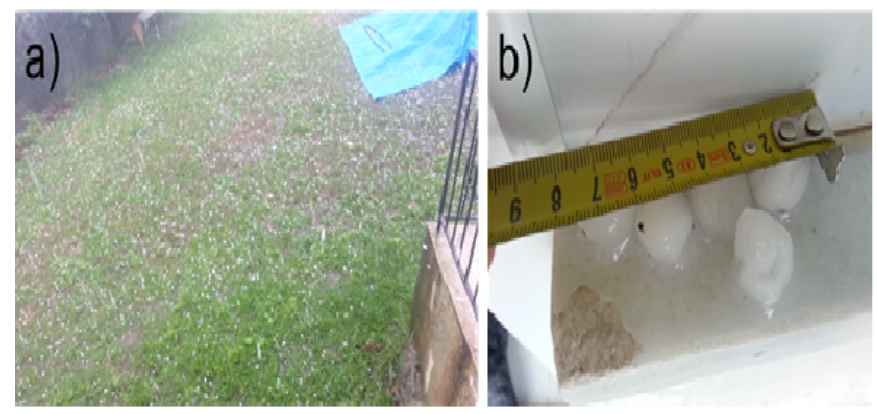

Figure 3. A screenshot from the video of the hailstorm (video: E. T. Özdemir) (a), and the diameter of hailstone about $1.5 \mathrm{~cm}$ (photo: E. T. Özdemir) (b).
Meteorological Analysis Tools: The used data in this study and their sources are described below.

Surface Pressure Charts (SPC) prepared by the Met Office (the United Kingdom), which are provided by the Wetter3.de (wetter3) web page, are used for synoptic analysis. Also, Global Forecast System (GFS) numerical weather prediction model $700-\mathrm{hPa}$ relative humidity $(\mathrm{RH})$ and $500-\mathrm{hPa}$ geopotential height and temperature charts which are prepared by Deutsche Wetterdienst (DWD) are downloaded from wetter3 web page to analyse the upper levels (Wetter3, 2018).

Skew-T Log-P diagram of Samsun that is prepared by the University of Wyoming is used for atmospheric sounding analysis (UWYO, 2018).

Natural Colour, Day Microphysics, Day Convective Storms, Red Green Blue (RGB) products of Meteosat Second Generation-3 (MSG-3) satellite that are provided by TSMS are used in satellite analysis. TSMS provides Trabzon Doppler Weather Radar, Maximum Display (Max) and Max Vertical Cross Section products. Max product shows the maximum values between two defined levels in the volumetric scan. This product gives an idea about the activity levels of the phenomenon and the strong cells. Also, vertical wind speed and echo tops (highest altitude of a threshold echo level) products are used (TSMS, 2018).

TITAN was designed as an algorithm in 1982 to identify and track the thunderstorms that are detected by weather radar. Through the years TITAN has been improved in two ways: (a) algorithm has refined in forecasting, analysis and climatology, (b) TITAN has become a combined system for data handling, analysis, and monitoring. TITAN is a complete software suite which can handle numerous different radar types and support satellite, lightning sensor, surface observation, and numerical products data (TITAN, 2018). The raw data of Trabzon radar were monitored and analysed by the TITAN software algorithm.

\section{FINDINGS}

Synoptic Analysis: SPC of August 31 ${ }^{\text {st }}, 2017$, Turkey is affected by a trough of monsoon low-pressure system (LPS). At 0600 UTC, two troughs are lying parallel to each other, over the Black Sea extending from Ukraine to Russia (Figure 4a). At 1200 UTC, the cold front of the occluded frontal system over Russia and Ukraine is running along the Eastern Black Sea Region, and a warm front is locating from the Eastern Black Sea Region to the north of the Central Anatolian Region. There is a convergence line on the 1200 UTC chart which is reaching out from the Eastern Anatolian Region to the south of Central Anatolian Region (Figure 4b). The frontal system has been moved to the northeast, and the warm front was located over the Eastern Black Sea Region at 1800 UTC (Figure 4c). 

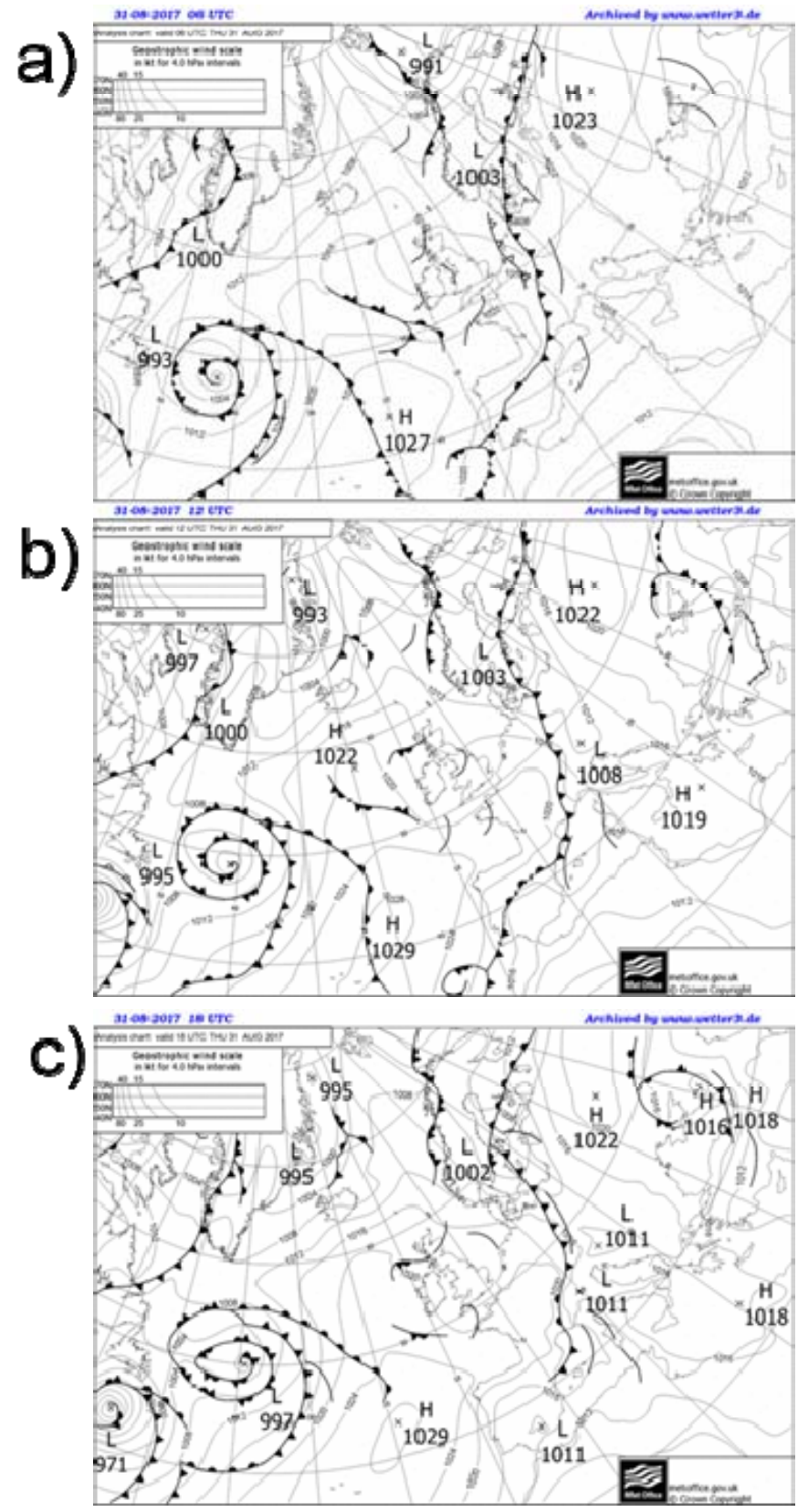

Figure 4. Surface pressure charts prepared by the Met Office (UK) at 06 UTC (a), at 12 UTC (b), and at 18 UTC (c) on $31^{\text {st }}$ August 2017 (Wetter3, 2018).

The relative humidity $(\mathrm{RH})$ band having a value of $75 \%$ at 700 -hPa level is lying over the Eastern Black Sea Region and the north of the Central Anatolian Region (Figure 5a). A sharp 500-hPa trough can be seen over the Mid-Black Sea and western part of Eastern Black Sea Region. The $500-\mathrm{hPa}$ values are $576 \mathrm{dam}$ height and $-12.5^{\circ} \mathrm{C}$ temperature over the region (Figure $5 \mathrm{~b}$ ).

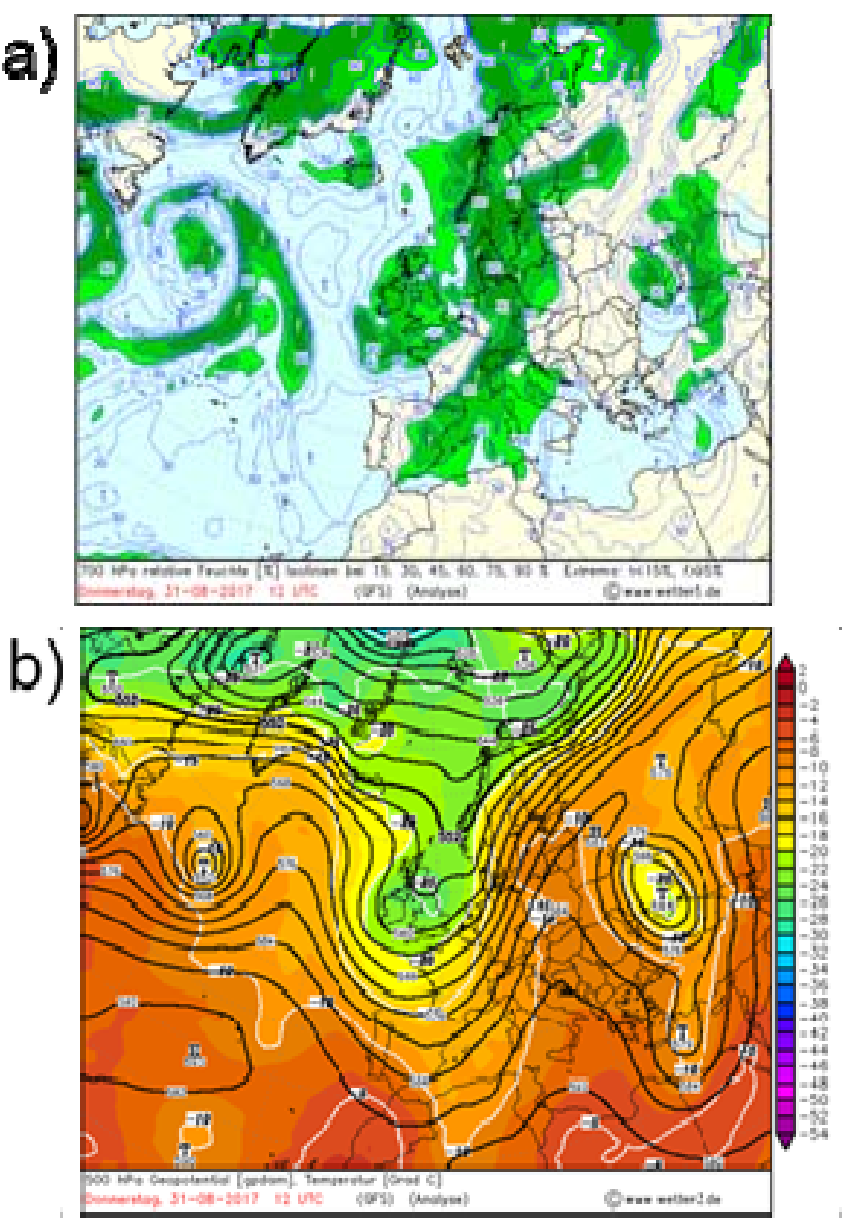

Figure 5. The upper-level charts of RH values (\%) 700-hPa (a), and geopotential height and temperature at $500-\mathrm{hPa}$ at $1200 \mathrm{UTC}$ on August 31 $1^{\text {st }}, 2017$ (b) (Wetter3, 2018).

Skew-T Log-P Diagram Analysis: The sounding diagram of Samsun at 1200 UTC on the event day, which is slightly longer than one hour before the event, is shown in Figure 6 (UWYO, 2018). The distance between Samsun Radiosonde Station and Yomra district is about $285 \mathrm{~km}$. The stability index values from the diagram: the Showalter stability index is 4.89 ( $\mathrm{SSI}>3$, thunderstorm is not possible); the lifted index is 5.42 ( $\mathrm{LI}>1$, thunderstorm is not possible); the $\mathrm{K}$ Index is $27.20 \quad(26 \leq \mathrm{K} \leq 30,40-60 \%$ chance of thunderstorms); the total totals index is 43.00 ( $\mathrm{TTI} \leq 43$, thunderstorm is not possible); the convective available potential energy is 0.00 (CAPE $<300$, marginally unstable) (UWYO, 2018; Çöleri et al., 2007). The RH value between $850-\mathrm{hPa}(1519 \mathrm{~m})$ and $700-\mathrm{hPa}(3113 \mathrm{~m})$ is $90 \%$ or more (UWYO, 2018). 


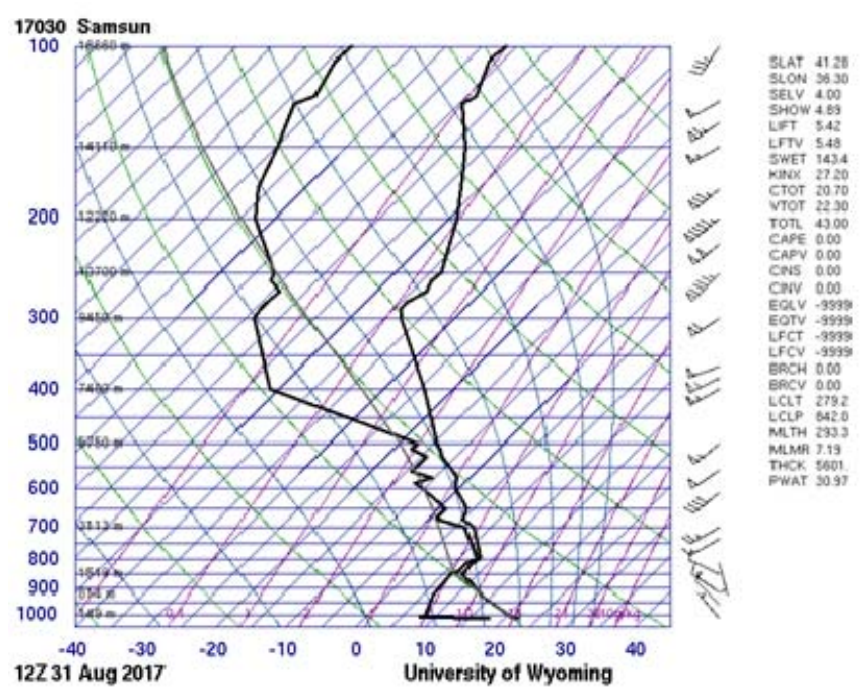

Figure 6. The Skew-T Log-P sounding diagram of Samsun at 1200 UTC on August 31 $1^{\text {st }}, 2017$ (UWYO, 2018).

Satellite Products Analysis: On the Natural Colour RGB view at 1315 UTC, cyan coloured clouds which include ice crystals with a big percentage can be seen over the Black Sea and Trabzon area (Figure 7a). At the same hour, the Day Microphysics RGB/Summer view, there are dark red coloured clouds over Trabzon area which indicate convective clouds with relatively bigger ice particles (Figure 7b). Red coloured clouds over Trabzon area show Cumulonimbus $(\mathrm{Cb})$ clouds with dissipating convection on the 1315 UTC Day Convective Storms RGB view (Figure 8).
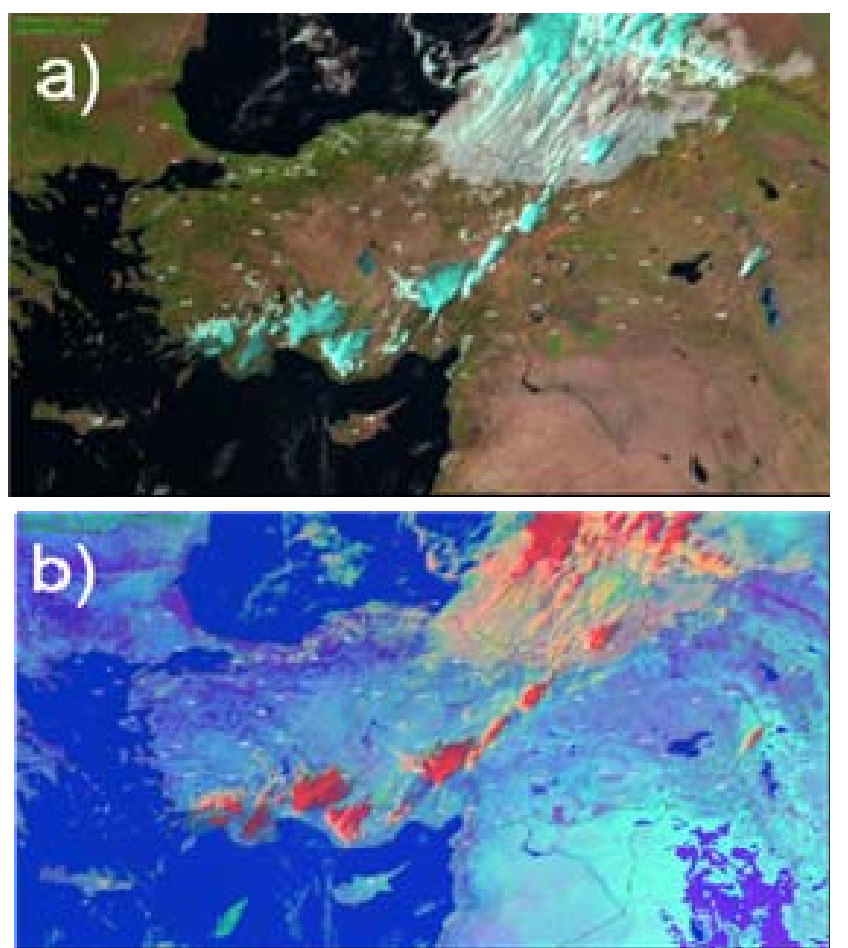

Figure 7. Satellite views of natural colour RGB (a) and microphysics RGB/summer (b) at 1315 UTC on August 31 $1^{\text {st }}, 2017$.

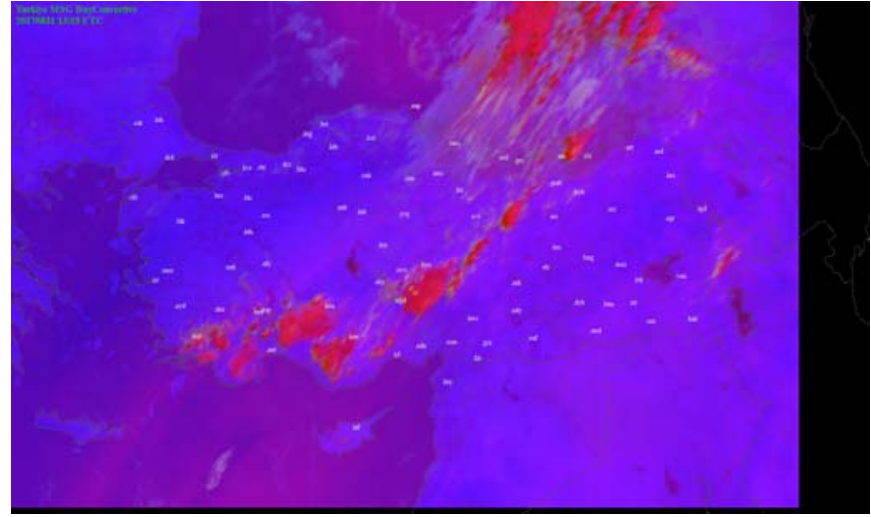

Figure 8. Convective storms RGB satellite view at 1315 UTC on August $31^{\text {st }}, 2017$

Radar Analysis: Storm cell with $60 \mathrm{dBz}$ reflectivity reaches out to the eastern districts of Trabzon at 1301 UTC Max product (Figure 9a). This cell has nearly $13 \mathrm{~km}$ cloud tops at 1308 UTC Max product (Figure 9b). At 1316 UTC, the cell is over Yomra District, and the tops are about $13 \mathrm{~km}$ height (Figure 9c). The storm cell is moving over the Black Sea, and the tops are over $13 \mathrm{~km}$ at 1323 UTC (Figure 9d).

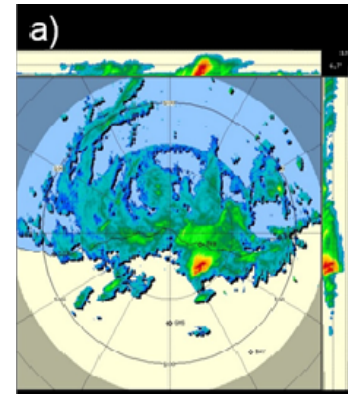

c)

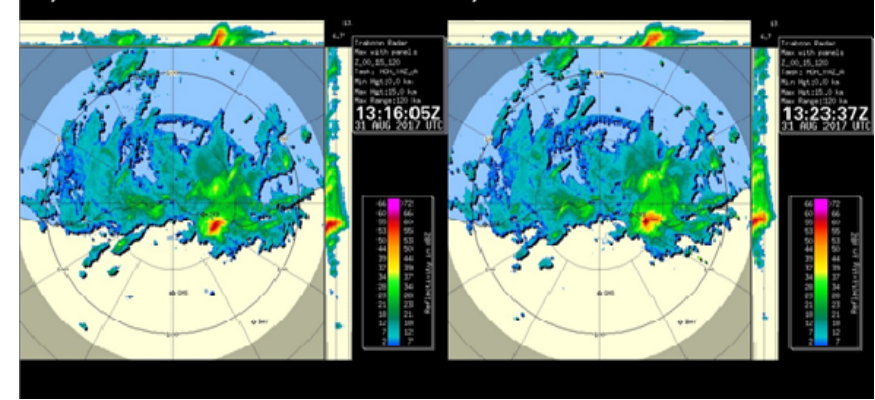

Figure 9. The views of Max radar product in Trabzon at 1301 UTC (a), 1308 UTC (b), 1316 UTC (c), and 1323 UTC (d) on August $31^{\text {st }}, 2017$.

The reflectivity value of $62 \mathrm{dBZ}$ can be seen at a vertical-cross section of 1308 UTC Max radar product (Figure 10a). The reflectivity value of $62 \mathrm{dBZ}$ indicates heavy rain and hail. The weak echo region (WER) and the bounded weak echo region (BWER) are prominent in the cross-section (Figure 10b). Also, the "V" notch can be seen at the same product (Figure 10c). 


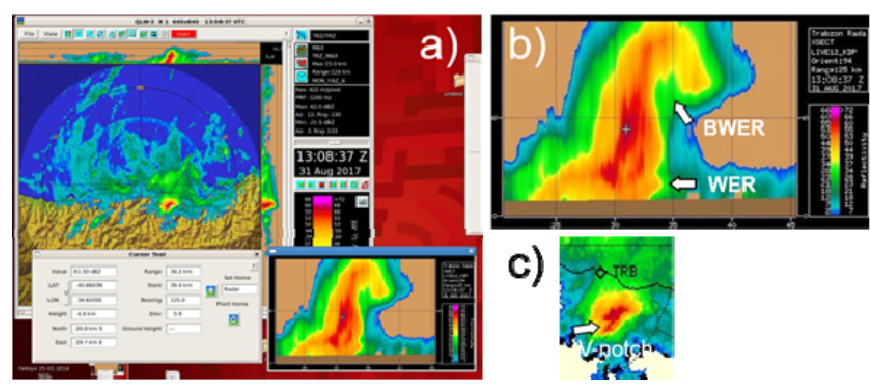

Figure 10. The vertical cross-section of Max radar product (a), WER and BWER at the vertical cross-section (b), and the V notch (c) at 1308 UTC on August 31 ${ }^{\text {st }}, 2017$.

TITAN Analysis: The TITAN algorithm recorded the storm cell with number 152. The algorithm tracked the cell with the same number and analysed all the variables throughout the whole data set. Outputs that are obtained from the analysis are interpreted at the time-history graphics (Foote et al., 2005).

The time-history graphic includes general cell parameters (Figure 11). Area graph denotes the covered area of the cell in $\mathrm{km}^{2}$. The covered area increased from $200 \mathrm{~km}^{2}$ to $400 \mathrm{~km}^{2}$ during the investigated period. The vertically integrated liquid (VIL) graph indicates about $40-55 \mathrm{~kg} / \mathrm{m}^{2}$ at the time of hailstorm. The precipitation flux (Pflux) graph shows vertically moving precipitation in $\mathrm{m}^{3} / \mathrm{s}$. During the whole lifetime of the cell, Pflux values are at the highest level at the time of hailstorm (1100-1200 m³ $/ \mathrm{s})$.

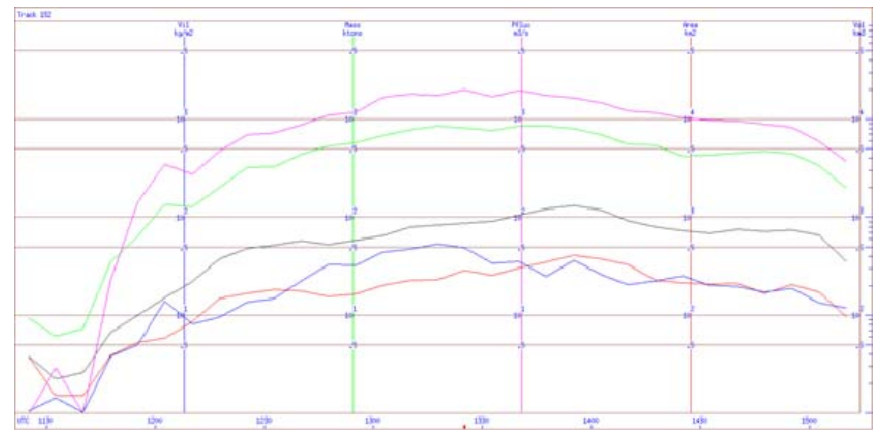

Figure 11. The TITAN general cell parameter time-history graphic.

The other time history graphic is about hail parameter (Figure 12). The vertically integrated hail mass (vihm) in this graph indicates calculated hail mass amount in $\mathrm{kg} / \mathrm{m}^{2}$. During the hailstorm, this value is about $50 \mathrm{~kg} / \mathrm{m}^{2}$. Foote-Kraus (FOKR) is a hail classification index. The FOKR graph shows cat 2 (hail including convective cells at a later time) and cat 3 (hailstorm) during the life of the cell. Probability of Hail (poh) is another hail classification index and indicates the possibility of hail with percent. The values of poh are 0.9 and 1.0 at the time of hailstorm. That means the probability of hail is $90-100 \%$. The last graph is hail mass (Hmass), which shows the calculated hail mass in kiloton, and these values reach the highest levels during the hailstorm (100-120 ktons).

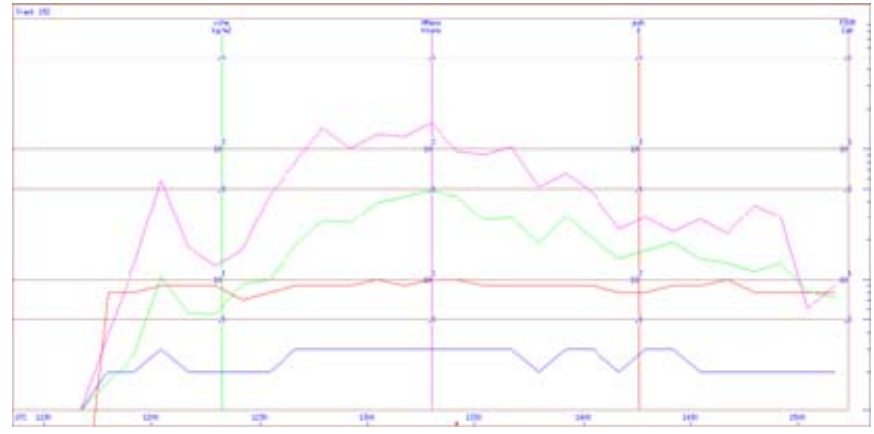

Figure 12. TITAN Hail Parameter time-history graphic.

\section{DISCUSSION and CONCLUSION}

A hailstorm event occurred on the rural part of Yomra in the afternoon on August 31 ${ }^{\text {st }}$, 2017. The hailstorm occurs during the hazelnut harvest season; therefore, it did not cause any damage to hazelnut production. In this study, the meteorological conditions of the event analysed.

First, the thunderstorm cell was not recorded by any automated weather station operated by TSMS. Hence, our analysis is limited to remote sensing products. We inspected national and local press about the hailstorm whether cause any damage to property or not (e.g., Kahraman et al., 2016). Fortunately, the event did not cause any damage due to its occurrence in a rural area. It should be noted that this kind of severe atmospheric events where take place in the rural regions, may not be recorded.

Second, hailstorms draw attention where they occur in the cities, which lead to economic losses or causalities. However, it may cause erosion in rural areas. The impact of hail on the ground surface can dissipate significant kinetic energy as a function of its size and velocity (Hagen et al., 1975; Macdonald et al., 2016), and hailstorms result in detachment of soil and erosion (e.g., Coppus and Imeson, 2002). Moreover, accompanying massive rainfall events following hailstorms can wash away the loose material from the ground surface. This situation can be exacerbated by the loss of erosion protection provided by vegetation (e.g., Rogers and Schumm, 1991; Yüksek and Yüksek, 2015) due to the destruction of plant cover induced by hailstone impact. Furthermore, the steepness of the terrain worsens vulnerability of the Black Sea Region to this kind of soil erosion, which is induced by hail and followed by heavy rain. Global warming may cause more frequently observed these severe events (Botzen et al., 2010). Hence, hail erosion will require more attention in the near future for soil conservation and environmental sustainability.

Third, the meteorological conditions during the event were a newly developing cold and warm fronts over the Black Sea and western part of Eastern Black Sea Region on the 1200 UTC surface chart. Also, RH at $700-\mathrm{hPa}$ was $75 \%$ $\mathrm{RH}$ and a sharp trough with cold air at 500-hPa level. The distance between Samsun and Yomra, Trabzon, is about 285 
$\mathrm{km}$, and the upper-level trough moved very fast. Hence, instability index values at the Samsun sounding chart were low. The convective activity can be detected on MSG3 Natural Colour RGB, MSG3 Day Microphysics RGB/Summer, and MSG3 Day Convective Storms RGB satellite products. Also, the trough which runs very fast can be seen on satellite views.

The maximum reflectivity values on Max products are; $61.0 \mathrm{dBZ}$ at $1238 \mathrm{UTC}, 59.0 \mathrm{dBZ}$ at $1246 \mathrm{UTC}, 60.0$ $\mathrm{dBZ}$ at $1301 \mathrm{UTC}, 62.0 \mathrm{dBZ}$ at $1308 \mathrm{UTC}, 62.0 \mathrm{dBZ}$ at 1316 UTC, and $62.5 \mathrm{dBZ}$ at $1323 \mathrm{UTC}$. These values point out hard rain and hailstorm. When maximum reflectivity observed at 1323 UTC, corresponding horizontal wind values at different levels of the atmosphere are 5 knots from $280^{\circ}$ at $2 \mathrm{~km}, 20$ knots from $200^{\circ}$ at $3 \mathrm{~km}$, and 65 knots from $010^{\circ}$ at $5 \mathrm{~km}$ height. Reflectivity values which exceed $40 \mathrm{dBz}$ in Echo Tops products (figure not given) at 1308 UTC and 1316 UTC are between $10-11 \mathrm{~km}$.

Finally, the main outcome from the TITAN analysis is the probability of hail parameter, which is more than $90 \%$. This percentage points out that hail is nearly guaranteed. Also, FOKR graph with cat three value clearly shows a hailstorm cell. The value of $400 \mathrm{~km}^{2}$ on the Area graph that indicates the covered area of the cell is important for analysis.

Thunderstorm cell climbs over $13 \mathrm{~km}$. The lifetime is more than 4 hours. The existence of WER and BWER, the observation of the $\mathrm{V}$ notch, relatively higher pflux values, and covered area about $400 \mathrm{~km}^{2}$, all these symptoms strengthen the likelihood of the thunderstorm cell to be a "supercell".

\section{ACKNOWLEDGEMENTS}

The authors thank Kenan Alparslan for his help TSMS for procurement of meteorological data. Emrah Tuncay Özdemir thanks to the Scientific and Technological Research Council of Turkey (TÜBİTAK) for support. Some parts of this study are published at the III. Meteorological Remote Sensing Symposium (Özdemir, 2017). The authors thank the editor and two anonymous reviewers for their comments, which contributed to improving the manuscript.

\section{REFERENCES}

Ackerman, S.A. \& Knox, J.A. (2015). Meteoroloji, atmosferimizi anlamak. Nobel Akademik Yayıncılık Eğitim Danışmanlık, pp. 339-379. (in Turkish)

Annanurov, S., Deniz, A. \& Özdemir, E.T. (2014). İstanbul fir sahası için Sigmet ve Airmet analizi. V. Ulusal Havacılık ve Uzay Konferansı, 8-10 Eylül 2014, Erciyes Üniversitesi, Kayseri. UHUK-2014-082. (in Turkish)
Baltaci, H., Akkoyunlu, B.O. \& Tayanc, M. (2018). An extreme hailstorm on 27 July 2017 in Istanbul, Turkey: Synoptic scale circulation and thermodynamic evaluation. Pure and Applied Geophysics, 175, 3727-3740. Doi:10.1007/s00024018-1841-x.

Botzen, W.J.W., Bouwer, L.M. \& van den Bergh, J.C.J.M. (2010). Climate change and hailstorm damage: Empirical evidence and implications for agriculture and insurance. Resource and Energy Economics, 32, 341-362. Doi: 10.1016/j.reseneeco.2009.10.004

Bowler, N.E., Pierce, C.E. \& Seed, A.W. (2006). STEPS: A probabilistic precipitation forecasting scheme which merges an extrapolation nowcast with downscaled NWP. Quarterly Journal of the Royal Meteorological Society, 132(620), 2127-2155. Doi: 10.1256/qj.04.100

Bunkers, M.J. (2018). Observations of right-moving supercell motion forecast errors. Weather and Forecasting, 33(1), 145-159. Doi: 10.1175/WAF-D17-0133.1

Chisholm A.J. \& Renick J.H. (1972). The kinematics of multicell and supercell Alberta hailstorms, Alberta Hail Studies, 1972. Res. Counc. Alberta Hail Stud. Rep. No. 72-2, pp. 24-31.

Coppus, R. \& Imeson, A.C. (2002). Extreme events controlling erosion and sediment transport in a semiarid sub-Andean valley. Earth Surface Processes and Landforms, 27, 1365-1375. Doi: 10.1002/esp.435

Cotton W.R. \& Anthes R.A. (1989). Storm and cloud dynamics. Academic press, pp. 455-463.

Çöleri M., Yayvan M., Deniz A., Turgut Ü., Eryılmaz A., Geçer C. \& Güser A. (2007). Hava analiz ve tahmin tekniği. MGM. (in Turkish)

Dixon M. \& Wiener G. (1993). TITAN: Thunderstorm identification, tracking, analysis, and nowcasting-A radar-based methodology. Journal of Atmospheric and Oceanic Technology, 10(6), 785-797. Doi: $10.1175 / 15200426(1993) 010<0785$ :TTITAA $>2.0 . \mathrm{C}$ $0 ; 2$

Foote G.B., Krauss T.W. \& Makitov V. (2005). Hail metrics using conventional radar. In Proc., 16th Conference on Planned and Inadvertent Weather Modification.

Germann, U. \& Zawadzki, I. (2002). Scale-dependence of the predictability of precipitation from continental radar images. Part I: Description of the methodology. Monthly Weather Review, 130(12), 2859-2873. Doi: 10.1175/15200493(2002)130<2859:SDOTPO $>2.0 . \mathrm{CO} ; 2$

Hagen, L.J., Lyles, L. \& Dickerson, J.D. (1975). Soil detachment from clods by simulated rain and hail. The Transactions of the ASAE, 18(3), 540-543. 
Kahraman, A., Tilev-Tanriover, Ş., Kadioglu, M., Schultz, D.M. \& Markowski, P.M. (2016). Severe hail climatology of Turkey. Monthly Weather Review, 144(1), 337-346. Doi: 10.1175/MWR-D-150337.1

King, A. T. \& Kennedy, A.D. (2019). North American supercell environments in atmospheric reanalyses and RUC-2. Journal of Applied Meteorology and Climatology, 58(1), 71-92. Doi:10.1175/JAMC-D18-0015.1

Li, P.W. \& Lai, E.S.T. (2004). Short-range quantitative precipitation forecasting in Hong Kong. Journal of Hydrology, 288(1), 189-209. Doi: 10.1016/j.jhydrol. 2003.11 .034

Macdonald, H., Infield, D., Nash, D.H. \& Stack, M.M. (2016). Mapping hail meteorological observations for prediction of erosion in wind turbines. Wind Energy, 19, 777-784. Doi: 10.1002/we.1854

Markowski, P.M., Hatlee, T.P. \& Richardson, Y.P. (2018). Tornadogenesis in the 12 May 2010 Supercell Thunderstorm Intercepted by VORTEX2 near Clinton, Oklahoma. Monthly Weather Review, 146(11), 3623-3650. Doi:10.1175/MWR-D-180196.1

NWS, (2018). https://www.weather.gov/lmk/supercell/ dynamics, last access 15 August 2018

Özdemir E.T., Deniz A., Sezen I., Aslan Z. \& Yavuz V. (2017). Investigation of thunderstorms over Ataturk International Airport (LTBA), Istanbul. Mausam, 68(1), 175-180.

Özdemir E.T. \& Deniz A. (2016). Severe thunderstorm over Esenboğa International Airport in Turkey on 15 July 2013. Weather, 71(7), 157-161. Doi: 10.1002/wea. 2740

Özdemir E.T. (2017). Trabzon ilinin Yomra ilçesinde meydana gelen dolu yağışının analizi, 31 August 2017, III. Meteorological Remote Sensing Symposium, 16-19 October 2017, Antalya. (in Turkish)

Özdemir, E.T. \& Deniz, A. (2014). A case study of the wet microburst on August 2, 2011 at Esenboga International Airport (LTAC), XXXII Ostiv Congress, Leszno, Poland, 30 July-6 August 2014.

Özdemir, E.T., Baltacı, H., Uluyazı, M. \& Deniz, A. (2015). Nowcasting uygulaması: 2 Şubat 2015 Atatürk Uluslararası Havalimanı örneği. II. Meteorolojik Uzaktan Algllama Sempozyumu, 3-5 Kasim 2015, Antalya, 480-499. (in Turkish)

Özdemir, E.T., Yavuz, V. \& Müslüm, M. (2017). Atatürk Uluslararası Havalimanı'nda meydana gelen downburst hadisesinin incelenmesi, III. Meteorolojik Uzaktan Algllama Sempozyumu, 16-19 Ekim 2017, Antalya. (in Turkish)
Özdemir, E. T., Yavuz, V., Deniz, A., Karan, H., Kartal, M. \& Kent, S. (2019). Squall line over Antalya: a case study of the events of 25 October 2014. Weather. Doi:10.1002/wea.3459

Putnam, B., Xue, M., Jung, Y., Snook, N. \& Zhang, G. (2019). Ensemble Kalman Filter Assimilation of Polarimetric Radar Observations for the 20 May 2013 Oklahoma Tornadic Supercell Case. Monthly Weather Review, (2019). Doi:10.1175/MWR-D-180251.1

Rogers, R.D. \& Schumm, S.A. (1991). The effect of sparse vegetative cover on erosion and sediment yield. Journal of Hydrology, 123(1-2), 19-24. Doi: 10.1016/0022-1694(91)90065-P

TITAN, (2018). http://www.rap.ucar.edu/projects/titan/home /whatis_titan.php, last access 29 November 2018.

TSMS, (2018). https://www.mgm.gov.tr/sondurum/radar. aspx $2 \mathrm{rG}=\mathrm{img} \& \mathrm{rR}=34 \mathrm{C} \& \mathrm{rU}=\mathrm{max} \# \mathrm{sfB}$, last access 29 November 2018

Türkeş, M. (2010). Klimatoloji ve meteoroloji. Kriter Yayınevi, 456-470. (in Turkish)

UWYO, (2018). http://weather.uwyo.edu/upperair/sounding. html, last access 29 November 2018

Wetter3, (2018). http://www1.wetter3.de, last access 29 November 2018

Wikipedia, (2018). https://en.wikipedia.org/wiki/Hook echo, last access 29 November 2018.

Yazmuhammedov, S., Deniz, A. \& Özdemir, E.T. (2014). İstanbul havalimanlarinin $\mathrm{Cb}$ ve oraj analizi. $V$. Ulusal Havacılık ve Uzay Konferansı, 8-10 Eylül 2014, Erciyes Üniversitesi, Kayseri. UHUK-2014084. (in Turkish)

Yavuz, V., Temiz, C., Özdemir, E.T., Deniz, A. (2015). Investigation of Accident Incident In-Flight Reports for The European Region. European Journal of Science and Technology, 2(5), 155-160. (in Turkish)

Yüksek, F. \& Yüksek, T. (2015). Growth performance of Sainfoin and its effects on the runoff, soil loss and sediment concentration in a semi-arid region of Turkey. Catena, 133, 309-317. Doi: 10.1016/j. catena.2015.05.018

\section{*Corresponding author's:}

Emrah Tuncay ÖZDEMIR

Meteoroloji Genel Müdürlüğü, Atatürk Havalimanı Meteoroloji Ofisi, 34149, Yeşilköy, İstanbul, Türkiye

E-mail: etozdemir@gmail.com

ORCID: https://orcid.org/0000-0003-4764-1625 